\title{
Bacteriocins of lactic acid bacteria as a hindering factor for biohydrogen production from cassava flour wastewater in a continuous multiple tube reactor
}

\author{
Simone Damasceno Gomes ${ }^{a}$, Lucas Tadeu Fuess ${ }^{b, *}$, Tatiana Mañunga ${ }^{c}$, \\ Paulo Clairmont Feitosa de Lima Gomes ${ }^{d}$, Marcelo Zaiat ${ }^{b}$ \\ a Graduate Program in Agricultural Engineering, State University of West Paraná, 2069 Universitária Street, 85819- \\ 210, Cascavel, PR, Brazil \\ b Biological Processes Laboratory, São Carlos School of Engineering, University of São Paulo, 1100 João Dagnone \\ Avenue, 13563-120, São Carlos, SP, Brazil \\ c Engineering School of Natural Resources and Environment, University of Valle, Calle 13 No 100-00, Santiago de \\ Cali, Colombia \\ d Institute of Chemistry of Araraquara, UNESP - Univ Estadual Paulista, 55 Prof. Francisco Degni Street, 14800-060, \\ Araraquara, SP, Brazil
}

\section{A R T I C L E I N F O}

\section{Article history:}

Received 1 August 2015

Received in revised form

9 October 2015

Accepted 11 November 2015

Available online 25 March 2016

Keywords:

Continuous multiple tube reactor

Cassava wastewater

Biohydrogen

Lactic acid bacteria

Bacteriocins

LC-MS/MS

\begin{abstract}
A B S T R A C T
Studies on fermentative systems applied to cassava processing wastewaters usually indicate favorable scenarios for biohydrogen $\left(\mathrm{BioH}_{2}\right)$ production, considering the appreciable levels of carbohydrates found on such wastewaters. To assess the suitability of cassava flour wastewater (CFWW), a high-strength effluent from cassava flour industries, for $\mathrm{BioH}_{2}$ production, a continuous multiple tube reactor (CMTR) was applied in bench-scale assays. The CMTR is an innovative bioreactor configuration that promotes continuous biomass discharge and prevents the accumulation of solids in the long-term. Continuous experiments were conducted using raw and heat-treated CFWW, with and without nutrient supplementation. Although the carbohydrate conversion exceeded $90 \%$, little to no hydrogen production was observed regardless of the feeding conditions. The poor performance of the CMTR could be associated with the presence of organic acids but is likely attributed primarily to bacteriocins Nisin A and Nisin Z in the CFWW, as an evidence of the presence of lactic acid bacteria. The type of cassava wastewater may severely affect hydrogen production; therefore, prior characterization of the CFWW influent is essential to determine its suitability for acidogenic systems.
\end{abstract}

๑ 2016 Hydrogen Energy Publications LLC. Published by Elsevier Ltd. All rights reserved.

\footnotetext{
* Corresponding author.

E-mail addresses: simone.gomes@unioeste.br (S.D. Gomes), ltfuess@sc.usp.br (L.T. Fuess), tati.anam@yahoo.com (T. Mañunga), pauloclair@gmail.com (P.C. Feitosa de Lima Gomes), zaiat@sc.usp.br (M. Zaiat). 


\section{Introduction}

Hydrogen production from the anaerobic bioconversion of organic residues (i.e. biohydrogen or $\mathrm{BioH}_{2}$ ) comprises a promising approach for the generation of energy, based on important environmental benefits compared to conventional thermo- and electrochemical processes, with emphasis on lower energy requirements [1]. Considering the implementation of $\mathrm{BioH}_{2}$ fermentative systems in full-scale treatment plants, the use of continuous systems is imperative to handle the continuous generation of wastewaters [2]. Although most studies on continuous $\mathrm{BioH}_{2}$ production by dark fermentation are based on the use of continuously stirred tank reactors (CSTRs), the occurrence of biomass washout in such systems may limit the activity of hydrogen producing bacteria (HPB) [3]. Therefore, reactor configurations that maintain high cell density within the systems, such as packed-bed (APBR), fluidized-bed (AFBR), sludge-bed (UASB), sequencing batch (ASBR) and membrane (AMBR) reactors, are considered attractive approaches to enhance hydrogen production in fermentative systems [4-6].

Focusing on fixed-bed systems, despite the suitability previously pointed, studies on $\mathrm{BioH}_{2}$ production often associate limitations to the application of APBRs in fermentative systems, considering unstable and decreasing production rates even for short-term operations [5,7-9]. The literature usually associates such poor performances with the accumulation of biomass within the reactors [10-12], which leads to inadequate conditions for the food-tomicroorganism ratio $(\mathrm{F} / \mathrm{M})$ or specific organic loading rate (SOLR). At excessive biomass concentrations, substrate shortage conditions may be established, which stimulates the activity of homoacetogenic bacteria, characterized by autotrophically growing on carbon dioxide and using molecular hydrogen as electron donor in the Wood-Ljungdahl pathway $[8,12,13]$. Decreasing $\mathrm{BioH}_{2}$ production in acidogenic systems submitted to excessive biomass concentrations may also result from both substrate competition between HPB and non-hydrogen producing bacteria and inhibitory effects from the accumulation of extracellular polymeric substances, as observed by Lee et al. [14] from the operation of an AMBR.

In this context, the continuous multiple tube reactor (CMTR), which is an innovative reactor configuration suitable for biological systems [15], may represent an alternative to overcome the limitations regarding the control of the SOLR. CMTRs are designed to provide a larger surface area to the attachment of solids compared to conventional tube reactors without support material [15], as the reaction region is formed by a group of parallel small diameter tubes. Simultaneously, the high superficial velocity applied to the tubes is expected to control the formation of the biofilm by continuously discharging solids accumulated in excess, which potentially maintains an adequate biomass concentration for $\mathrm{BioH}_{2}$ production. The concept of the CMTR is analogous to multitubular heat exchangers in chemical engineering, in which the larger surface area enhances both heat dissipation in highly exothermic processes and heat absorption in highly endothermic processes [16].
The applicability of the CMTR to fermentative hydrogen production was initially tested by Gomes et al. [15], who achieved continuous $\mathrm{BioH}_{2}$ production for periods of approximately 20-25 days in experiments that used sucrose as the carbon source. However, the literature still lacks studies on the application of the CMTR in fermentative anaerobic systems that use real wastewaters as substrate. Organic matterrich wastewaters, such as vinasses and effluents from biodiesel production, cassava processing and cheese whey, constitute important substrates for $\mathrm{BioH}_{2}$ production, as residual compounds from agroindustrial processes may be suitable substrates for HPB. Lin et al. [17] reviewed aspects regarding hydrogen production from different wastewaters in fermentative systems, assessing the feasibility of bioenergy recovery through $\mathrm{BioH}_{2}$ in integrated acidogenicmethanogenic anaerobic processes. The aforementioned authors compiled a list of operating conditions in which $\mathrm{BiOH}_{2}$ production was attained, including substrate concentration, $\mathrm{pH}$, temperature and hydraulic retention time (HRT) ranging respectively from 0.25 to $160 \mathrm{~g} \mathrm{COD} \mathrm{L}^{-1}, 4-8,23-60{ }^{\circ} \mathrm{C}$ and $0.5-72 \mathrm{~h}$, with various types of reactor configuration. Among the available wastewater streams potentially suitable to $\mathrm{BiOH}_{2}$ production, this study highlights the use of the cassava flour wastewater (CFWW), which is a type of cassava processing wastewater characterized by high levels of carbohydrates (approximately $37 \mathrm{~g} \mathrm{~L}^{-1}$ as fructose and glucose) and a high chemical oxygen demand (COD, approximately $60 \mathrm{~g} \mathrm{~L}^{-1}$ ) [18]. Theoretically, the high organic matter content of cassava wastewaters, especially in terms of readily available sugars, makes these residues suitable substrates for hydrogen production, as HPB use carbohydrates as their main carbon source.

The literature includes several studies on $\mathrm{BioH}_{2}$ production from cassava wastewaters using different approaches, such as the application of continuous and batch processes [19-22]; different continuous reactor configurations, such as CSTR, ASBR and AFBR [22-25]; mesophilic and thermophilic conditions [22,24]; and co-digestion with other substrates $[25,26]$. Although these studies typically report successful scenarios for $\mathrm{BioH}_{2}$ production from cassava wastewaters, eventual performance losses inherent in acidogenic systems may be observed due to limitations in the availability of nutrients [27] and the presence of undesirable microorganisms and inhibitory compounds in the wastewaters. Lucas et al. [22] observed higher $\mathrm{BioH}_{2}$ production from synthetic sucrose-based effluent compared to cassava processing wastewater, which may indicate the occurrence of inhibitory processes over hydrogen production from cassava-related byproducts. In fact, depending on the type of processing applied to cassava, specific metabolic compounds that result from the presence of lactic acid bacteria (LAB) may be found in the wastewater, such as organic acids, especially lactic acid $[28,29]$ and bacteriocins [30,31]. Bacteriocins are biologically active peptides, which present antimicrobial properties against other bacterial species, increasing the permeability of cell membranes and enhancing the efflux of essential compounds in such bacteria [32]. Therefore, in addition to the competition between LAB and HPB by substrate [33], the excretion of bacteriocins by LAB may inhibit $\mathrm{BioH}_{2}$ production by directly damaging the cellular membrane of 
Clostridium sp. [30-34]. which are the main HPB found in acidogenic reactors.

To overcome performance losses related to both the presence of bacteriocins and limitations on the availability of reducing sugars, different approaches may be applied to acidogenic systems that treat cassava wastewaters. The main alternatives include the application of pretreatment methods to the wastewater [35], the operation of the reactors under thermophilic conditions [19] and the co-digestion of the wastewater with other organic substrates [25,26]. Leaño and Babel [35] applied several pretreatment methods to cassava wastewater (i.e., sonication, OPTIMASH BG and $\alpha$-amylase) to optimize hydrogen production in batch anaerobic fermentation. These methods significantly affected the overall hydrogen production rate and substrate conversion efficiency. The $\alpha$-amylase pretreatment had the highest performance because it supplied the HPB with readily available sugars. Wang et al. [26] evaluated the co-digestion of cassava wastewater with cassava excess sludge, pig manure, cow manure, and waste activated sludge and observed increased hydrolysis and acidification in all co-digestions. Rosa et al. [25] evaluated the potential for the co-fermentation of cassava processing wastewaters and glucose in an AFBR using two types of sludge. The cassava wastewater was subjected to acid hydrolysis with sulfuric acid and was then heated at $120^{\circ} \mathrm{C}$ for $30 \mathrm{~min}$ to promote the hydrolysis of the starch chains. In addition to the benefits described above, co-digestion may also reduce the effects of toxic compounds that are found in cassava wastewaters by diluting the raw effluent and this could also explain the increased performances observed in such cases.

Therefore, based on the points briefly discussed, this paper investigated the applicability of both the CMTR and CFWW for the biological production of hydrogen. Mesophilic temperature conditions $\left(25^{\circ} \mathrm{C}\right)$ were applied, and the influence of different factors, such as the provision of nutrients and the application of heat treatment to the wastewater, were tested, in an attempt to overcome eventual limitations of the cassava wastewater. The performance of the reactor was associated with intrinsic compositional characteristics of the CFWW, aiming to determine the suitability of this wastewater for the production of hydrogen. This study is the first report to assess $\mathrm{BioH}_{2}$ production from real wastewater in a CMTR.

\section{Materials and methods}

\section{Continuous multiple tube reactor}

This study used a bench-scale (approximately 1 L) CMTR, as previously described by Gomes et al. [15]. The constructive aspects of the reactor are depicted in Fig. 1 . The reaction region of the reactor was composed of 12 long PVC tubes $(680 \mathrm{~mm})$ of small diameter $(12 \mathrm{~mm})$. The inner surfaces of the tubes were sanded to provide adequate conditions for biomass attachment. Additionally, a fixed-bed was placed in the outlet chamber using polypropylene rings in all assays to prevent excessive biomass washout during experiments.

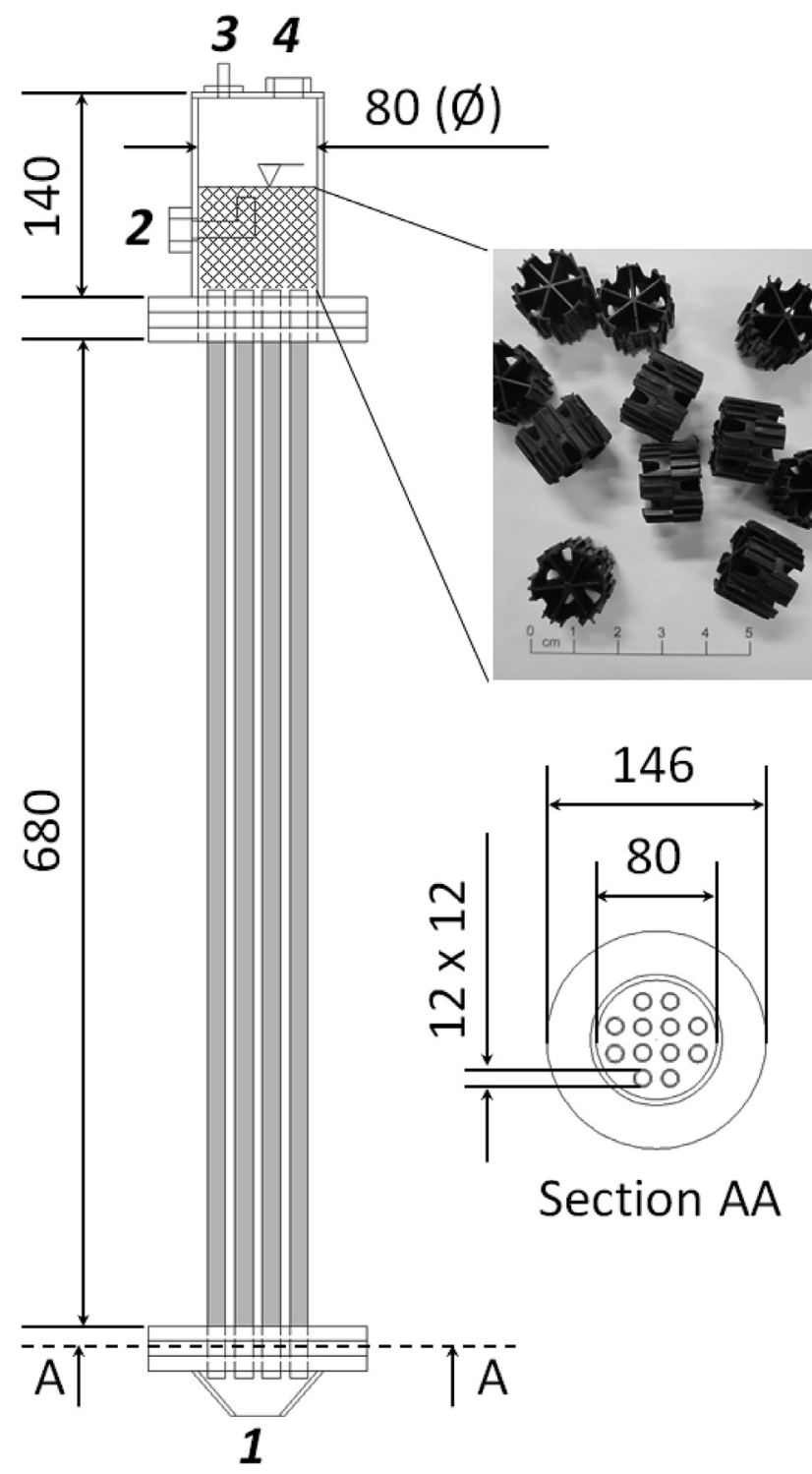

Fig. 1 - Components of the CMTR (measurements in millimeters) and support material used in the outlet chamber. Legend: 1 - feed port, 2 - effluent collection, 3 port to gas meter, 4 - biogas collection septum.

\section{Cassava flour wastewater and lab-made sucrose-based effluent}

The CMTR was continuously fed with CFWW or lab-made sucrose-based wastewater. CFWW samples were collected from a cassava flour factory located in Santa Maria, SP, Brazil. The characteristics of the CFWW were the following: $\mathrm{pH}=5.0$, total carbohydrates $(\mathrm{CH})=30 \mathrm{~g} \mathrm{~L}^{-1}\left(19.5 \mathrm{~g} \mathrm{~L}^{-1}\right.$ as glucose and fructose), and total chemical oxygen demand (TCOD) $=55 \mathrm{~g} \mathrm{~L}^{-1}$. The $\mathrm{pH}$ of the CFWW was adjusted to 6.5 by adding sodium bicarbonate $\left(\mathrm{NaHCO}_{3}\right)$ prior to feeding the reactor. The lab-made wastewater was prepared with sucrose and urea as the carbon and nitrogen sources, respectively, in order to establish an optimal C/N ratio of 140 [11]. Nutrients were supplied to the lab-made wastewater using a solution 
that was previously described by Del Nery [36], which included $\mathrm{SeO}_{2}\left(0.144 \mathrm{~g} \mathrm{~L}^{-1}\right), \mathrm{CaCl}_{2} \cdot 6 \mathrm{H}_{2} \mathrm{O}\left(8.24 \mathrm{~g} \mathrm{~L}^{-1}\right), \mathrm{KH}_{2} \mathrm{PO}_{4}\left(21.44 \mathrm{~g} \mathrm{~L}^{-1}\right)$, $\mathrm{K}_{2} \mathrm{HPO}_{4}\left(5.20 \mathrm{~g} \mathrm{~L}^{-1}\right), \mathrm{Na}_{2} \mathrm{HPO}_{4}\left(11.04 \mathrm{~g} \mathrm{~L}^{-1}\right), \mathrm{NiSO}_{4} \cdot 6 \mathrm{H}_{2} \mathrm{O}$ (2.00 $\left.\mathrm{g} \mathrm{L}^{-1}\right), \mathrm{FeSO}_{4} \cdot 7 \mathrm{H}_{2} \mathrm{O}\left(10.00 \mathrm{~g} \mathrm{~L}^{-1}\right), \mathrm{FeCl}_{3} \cdot 6 \mathrm{H}_{2} \mathrm{O}\left(1.00 \mathrm{~g} \mathrm{~L}^{-1}\right)$ and $\mathrm{CoCl}_{2} \cdot 2 \mathrm{H}_{2} \mathrm{O}\left(0.16 \mathrm{~g} \mathrm{~L}^{-1}\right)$. The $\mathrm{pH}$ of the sucrose-based effluent was also adjusted to 6.5 by adding $\mathrm{NaHCO}_{3}(6 \mathrm{mM})$ and concentrated hydrochloric acid ( $\mathrm{HCl} ; 3 \mathrm{mM})$.

\section{Operating conditions and inoculation}

The CMTR was operated under controlled temperature conditions $\left(25^{\circ} \mathrm{C}\right)$ with an applied organic loading rate (OLR) of $24 \mathrm{~g} \mathrm{CH} \mathrm{L}^{-1} \mathrm{~d}^{-1}$ and a hydraulic retention time (HRT) of $4 \mathrm{~h}$. Regardless of the wastewater type, the influent $\mathrm{CH}$ concentration was adjusted to $4 \mathrm{~g} \mathrm{~L}^{-1}$ by diluting the CFWW and adding the proper amount of sucrose during the preparation of the lab-made effluent. Three assays were conducted, including: assay 1 (E1) - CMTR fed with diluted CFWW $\left(\mathrm{CH}=4 \mathrm{~g} \mathrm{~L}^{-1}\right)$; assay 2 (E2) - CMTR fed with lab-made wastewater $\left(\mathrm{CH}=4 \mathrm{~g} \mathrm{~L}^{-1}\right)$ for 9 days and then with diluted CFWW $\left(\mathrm{CH}=4 \mathrm{~g} \mathrm{~L}^{-1}\right)$ subjected to heat treatment $\left(121{ }^{\circ} \mathrm{C}\right.$; $15 \mathrm{~min}$ ); and assay 3 (E3) - CMTR fed with diluted CFWW $\left(\mathrm{CH}=4 \mathrm{~g} \mathrm{~L}^{-1}\right)$ subjected to heat treatment $\left(121^{\circ} \mathrm{C} ; 15 \mathrm{~min}\right)$ and supplemented with nutrients [36]. In E2, the initial feeding of the CMTR with sucrose-based wastewater was conducted to enhance the establishment of HPB populations within the reactor, as in previous studies $\mathrm{BioH}_{2}$ production from such effluent was attained $[9,12,15]$.

For each assay, the reactor was inoculated by the natural fermentation of the effluent [37]. A given volume of raw CFWW (E1) or lab-made wastewater (E2 and E3) was maintained at ambient conditions for three days to stimulate the self-fermentation of the carbohydrates. The acidified substrate was then pumped into the reactor in a closed circuit for five days to allow the attachment of the biomass to the inner surfaces of the tubes.

\section{Performance evaluation: analytical methods}

The performance of the reactor was assessed based on the $\mathrm{pH}$, total carbohydrates $(\mathrm{CH})$, volatile fatty acids (VFA), solvents, biogas composition and flow rate. Prior to the analyses of COD and total carbohydrates, the samples were filtered with 1.22$\mu \mathrm{m}$ membranes. The $\mathrm{pH}$ values were obtained according to the procedures described by the Standard Methods for the Examination of Water and Wastewater [38]. The total carbohydrates analyses were based on the method proposed by Dubois et al. [39]. VFA and solvents were analyzed with a highperformance liquid chromatography system (HPLC, Shimadzu Scientific Instruments, Columbia, MD, USA) equipped with a pump (LC-10ADVP), an autosampler (SIL-20A HT), a column oven (CTO-20A) at $43^{\circ} \mathrm{C}$, a UV-diode array detector (SDP-M10 AVP), a refraction index detector (RID-10A), a system controller (SCL-10AVP) and an Aminex HPX-87H column (300 mm, $7.8 \mathrm{~mm}$, BioRad). The mobile phase consisted of sulfuric acid $(0.01 \mathrm{~N})$ at $0.5 \mathrm{~mL} \mathrm{~min}^{-1}$ [9]. In this case, the samples were filtered with $0.22-\mu \mathrm{m}$ membranes prior to the analyses. The biogas flow rate was measured with a gas meter (MGC-1 V30, Dr.-Ing. Ritter Apparatebau GMBH \& CO. KG, Bochum, Germany). The biogas composition (hydrogen, carbon dioxide and methane) was determined with a gas chromatograph (GC-2010, Shimadzu Scientific Instruments, Columbia, MD, USA) equipped with a thermal conductivity detector (GC/TCD) with argon as the carrier gas and a CARBOXEN 1010 Plot column $(30 \mathrm{~m}, 0.53 \mathrm{~mm})$. The temperatures of the injector and detector were maintained at $220{ }^{\circ} \mathrm{C}$ and $230^{\circ} \mathrm{C}$, respectively. The column had an initial temperature of $130{ }^{\circ} \mathrm{C}$ and was heated to $135^{\circ} \mathrm{C}$ at a rate of $46^{\circ} \mathrm{C} \min ^{-1}$ [40].

The presence of bacteriocins was also analyzed in both the raw and heat-treated CFWW using liquid chromatography coupled with tandem mass spectrometry (LC-MS/MS). In this case, the samples were also filtered with $0.22-\mu \mathrm{m}$ membranes prior to the analyses. A solid phase extraction (SPE) column with the hydrophilic-lipophilic balanced polymer Oasis HLB was acquired from Waters (Milford, MA, USA) and applied to the online sample preparation. The samples were introduced in backflush mode into the SPE column by an aqueous mobile phase (100\% ultra-pure water). Simultaneously, the analytical column (Agilent Poroshel EC18 column $50 \times 2.1 \mathrm{~mm} \times 2.7 \mu \mathrm{m}$ ) was conditioned by flushing the mobile phase that was present in pump B. At 3.01 min, the valve switched to position $B$, which allowed the pre-concentrated analytes to elute from the SPE column in the opposite direction toward the sample loading end to the analytes in the analytical column and the MS detector. The mobile phase that was used in binary pump $\mathrm{B}$ was a mixture of ultra-pure water (A) and $0.1 \%$ formic acid

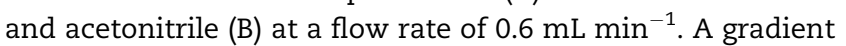
elution was programmed in pump B, which started with $95 \%$ of A isocratically for $3.1 \mathrm{~min}$. From 3.1 to $9 \mathrm{~min}$, the mobile phase linearly decreased to $35 \%$ of $A$ and then linearly to $5 \%$ of A between 10 and $14 \mathrm{~min}$. A hybrid triple quadrupole-linear ion trap mass spectrometer (QTRAP 5500, AB SCIEX, Foster, CA, USA) with a turbo ion spray source was coupled to the LC system described above. The MS/MS system was operated in the enhanced product ion (EPI) scan mode to detect $[\mathrm{M}+\mathrm{H}]^{4+}$ and $[\mathrm{M}+\mathrm{H}]^{5+}$ forms from Nisin and its degradation products. The scan mode was performed at $1000 \mathrm{Da} \mathrm{s}^{-1}$ in the 100-1000 Da mass range. The source-dependent parameters were optimized following Schneider et al. [41]: curtain gas (CUR) of 30 psi, nitrogen collision gas (CAD) at medium, source temperature (TEM) of $600{ }^{\circ} \mathrm{C}$, ion spray voltage of $5500 \mathrm{~V}$, ion source gases GS1 and GS2 at 60 psi.

The response variables that were used to assess the performance of the reactor under the different conditions included the total carbohydrates and/or sucrose conversion efficiency $\left(\mathrm{EC}_{\mathrm{CH}}\right.$, in \%), the biogas flow rate (BFR, in $\mathrm{mL} \mathrm{h}^{-1}$ ), the volumetric hydrogen production rate (VHPR, in $\mathrm{mL} \mathrm{H}_{2} \mathrm{~L}^{-1} \mathrm{~h}^{-1}$ ), the molar hydrogen flow rate (MHFR, in $\mathrm{mmol} \mathrm{H}_{2} \mathrm{~h}^{-1}$ ) and the hydrogen yield ( $\mathrm{HY}$, in $\mathrm{mol} \mathrm{H}_{2} \mathrm{~mol}^{-1} \mathrm{CH}$ ).

\section{Results and discussion}

\section{CMTR performance assessment: substrate conversion and hydrogen production}

The performance of the CMTR was assessed using the three assays previously described: E1 - reactor fed with diluted CFWW ( $\mathrm{CH}$ of $4 \mathrm{~g} \mathrm{~L}^{-1}$ ), E2 - reactor fed with sucrose-based effluent $\left(\mathrm{CH}\right.$ of $4 \mathrm{~g} \mathrm{~L}^{-1}$ ) and then with diluted $(\mathrm{CH}$ of 
$\left.4 \mathrm{~g} \mathrm{~L}^{-1}\right)$ and heat-treated $\left(121^{\circ} \mathrm{C}, 15 \mathrm{~min}\right) \mathrm{CFWW}$, and $\mathrm{E} 3-$ reactor fed with diluted $\left(\mathrm{CH}=4 \mathrm{~g} \mathrm{~L}^{-1}\right)$, heat-treated $\left(121^{\circ} \mathrm{C}\right.$, $15 \mathrm{~min}$ ) and nutrient-supplemented CFWW. The reactor was operated in continuous mode for 7, 23 and 10 days, respectively with assays E1, E2 and E3. The duration of the assays varied according to the temporal $\mathrm{BioH}_{2}$ production, so that the experimental runs were interrupted when at least three consecutive negligible values were obtained for the response-variables VHPR, MHFR and HY. Table 1 presents performance data regarding carbohydrates conversion and hydrogen production for the three assays (E1-E3), whereas the temporal profiles of the carbohydrate conversion efficiency are shown in Fig. 2. In E1 and E3, when only CFWW was used as the substrate, the carbohydrate conversion efficiency exceeded $90 \%$ for the entire operating period. In E2, the carbohydrate conversion efficiency was lower when the CMTR was fed with sucrose-based wastewater (approximately 50-60\%; Fig. 2, Table 1). Higher efficiencies $(>80 \%)$ were observed only after the application of CFWW. Although both wastewaters were rich in easily degradable carbon sources, most of the carbohydrate fraction in the CFWW was composed of readily available sugars to the HPB, i.e., glucose and fructose [18]. These compositional characteristics may account for the different patterns observed for the conversion of carbohydrates in the assays because the consumption of sucrose requires a hydrolysis step prior to the conversion to metabolites.

The temporal profiles of the response variables associated with hydrogen production, i.e., BFR, VHPR, MHFR and HY, are depicted in Fig. 3. While most of the carbohydrate fraction (>90\%) was consumed in E1 (Fig. 2, Table 1), no biogas, and consequently no hydrogen, was detected. In fact, Lucas et al. [22] observed higher hydrogen production rates using labmade wastewaters as a substrate, which suggests that inhibitory effects on the acidogenic bacteria may occur when cassava wastewaters are applied to fermentative systems. The main inhibitory compounds that can be found in such wastewaters include organic acids and bacteriocins, which are further discussed. However, several studies have successfully demonstrated hydrogen production from cassava wastewaters [19,20,22,25,26,35,42]. Comparative data from continuous $\mathrm{BioH}_{2}$-fermentative systems applied to cassava processing wastewaters are also compiled in Table 1 . The literature usually indicates substrate conversion levels higher than $80 \%$ for such wastewaters, whereas $\mathrm{BioH}_{2}$ production depends on the operating conditions applied to the reactors, as well as from the type of sludge used. Nevertheless, VHPR values usually higher than $40-50 \mathrm{~mL} \mathrm{H}_{2} \mathrm{~L}^{-1} \mathrm{~h}^{-1}$ are reported, regardless of the reactor type and operating conditions (Table 1).

In an attempt to identify the factors that caused the poor performance in $\mathrm{E} 1$, the negative effects of $\mathrm{LAB}$ in the reactor were also investigated. Several studies have indicated the presence of these microorganisms in cassava-related products. According to Obadina et al. [43], Lactobacillus plantarum typically plays an important role in the fermentation of cassava, so that the production of bacteriocins may directly inhibit $\mathrm{BioH}_{2}$ evolution by damaging the cellular membrane of HPB $[30,31,33,34]$.
Because bacteriocins are protein-rich substances, i.e., their structural arrangements may deteriorate when they are exposed to high temperatures [44], the CFWW samples were submitted to heat treatments in E2 and E3. In E2, the production of hydrogen gradually decreased (Fig. 3) a few days after the introduction of heat-treated wastewater (day 10) and finally ceased on day 18. Maximum VHPR (42.2 $\left.\mathrm{ml} \mathrm{H}_{2} \mathrm{~L}^{-1} \mathrm{~h}^{-1}\right)$ and $\mathrm{HY}\left(0.93 \mathrm{~mol} \mathrm{H}_{2} \mathrm{~mol}^{-1} \mathrm{CH}\right)$ observed in $\mathrm{E} 2$, when CFWW was applied to the CMTR (Table 1), most likely resulted from remaining fractions of sucrose-based wastewater within the reactor, considering the decreasing patterns observed for $\mathrm{BioH}_{2}$ production from the 10th day of operation onwards (Fig. 3) In E3, VHPR peaked at $52.97 \mathrm{~mL} \mathrm{H}_{2} \mathrm{~L}^{-1} \mathrm{~h}^{-1}$ (day 2; Fig. 3, Table 1), which was similar to the lower limits of $\mathrm{BioH}_{2}$ production data reported in the literature for cassava processing wastewaters (42.9-62.5 $\mathrm{mL} \mathrm{H}_{2} \mathrm{~L}^{-1} \mathrm{~h}^{-1}$, Table 1). The carbohydrate conversion efficiencies were also high (at least $90 \%$ ) in both E2 and E3 (Fig. 2, Table 1). However, hydrogen production quickly decreased and terminated even in the presence of the heat-treated wastewater with or without nutrient supplementation (approximately day 4 in E3, Fig. 3). This indicates that the problems were not attributed to a lack of nutrients. Furthermore, in a previous study on the application of labmade wastewater to a CMTR [15], continuous hydrogen production was observed for 24 days. Based on the results obtained herein, a maximum value of $2.07 \mathrm{~mol} \mathrm{H}_{2} \mathrm{~mol}^{-1} \mathrm{CH}$ was observed for the application of sucrose-based synthetic wastewater to the CMTR (E2, Table 1), which is slightly higher than the maximum value reported by Amorim et al. [20] (Table 1). Therefore, such results indicate that $\mathrm{BioH}_{2}$ production is possible in a CMTR and suggests that the negative results observed in this study could be associated with the presence of inhibitory metabolic compounds in the CFWW, such as organic acids and/or bacteriocins.

\section{Evaluation of organic acids in the raw, heat-treated and acidified CFWW}

Fig. 4 depicts the proportions of organic acids that were found in the raw, heat-treated and acidified CFWW. Propionic acid $(\mathrm{PrH})(66-71 \%)$ and butyric acid $(\mathrm{BuH})(5-11 \%)$ were the main metabolites in the raw and heat-treated CFWW samples, whereas lactic acid ( $\mathrm{LaH})$ accounted for only $3 \%$ of the detected VFAs (Fig. 4). This pattern contradicts the expected composition for cassava wastewaters when considering the potential presence of high concentrations of $\mathrm{LaH}$ as a direct result of the presence of LAB in such residues. LAB are grampositive non-sporulating bacteria which produce LaH either as the sole or as a major metabolic product from fermentation, i.e., respectively homo- and heterofermentative pathways [45]. However, LaH may be further oxidized to other VFA in acidogenic systems, such as $\mathrm{PrH}$ and $\mathrm{BuH}$. According to Madigan et al. [45], certain propionic acid bacteria, such as Propionibacterium, produce $\mathrm{PrH}$ as the main product from lactate fermentation, as observed in Reaction (1) [46]. These microorganisms may also produce propionic acid using glucose as substrate. LaH may also be converted to BuH by certain microbial populations, which could explain the average-to-high 


\begin{tabular}{|c|c|c|c|c|c|c|c|c|c|c|}
\hline \multirow[t]{2}{*}{ Cassava wastewater } & \multirow[t]{2}{*}{ Inoculum } & \multirow[t]{2}{*}{ Reactor } & \multicolumn{4}{|c|}{ Operating conditions } & \multicolumn{3}{|c|}{ Reactor performance } & \multirow[t]{2}{*}{ Reference } \\
\hline & & & $\begin{array}{c}\text { OLR } \\
\left(g^{-1} \operatorname{COD~L}^{-1} \mathrm{~d}^{-1}\right)\end{array}$ & $\begin{array}{c}\text { HRT } \\
(\mathrm{h})\end{array}$ & $\begin{array}{c}\text { Temperature } \\
\left({ }^{\circ} \mathrm{C}\right)\end{array}$ & $\mathrm{pH}(-)$ & $\begin{array}{c}\text { Substrate } \\
\text { conversion (\%) }\end{array}$ & $\begin{array}{c}\text { VHPR } \\
\left(\mathrm{mL} \mathrm{H}_{2} \mathrm{~L}^{-1} \mathrm{~h}^{-1}\right)\end{array}$ & $\begin{array}{c}\mathrm{HY} \\
\text { (mol H} \mathrm{mol}_{2} \mathrm{~m}^{-1} \text { substrate) }\end{array}$ & \\
\hline CFWW $\left(4 \mathrm{~g}-\mathrm{CH} \mathrm{L}^{-1}\right)$ & $\mathrm{NF}$ & CMTR & $24^{\mathrm{a}}$ & 4 & 25 & 6.5 & $95.7^{\mathrm{b}}$ & 0 & 0 & E1, this study \\
\hline $\begin{array}{l}\text { SuBSW }\left(4 \mathrm{~g}-\mathrm{CH} \mathrm{L}^{-1}\right)+\mathrm{CFWW}^{\mathrm{c}} \\
\left(4 \mathrm{~g}-\mathrm{CH} \mathrm{L}^{-1}\right)\end{array}$ & NF & CMTR & $24^{\mathrm{a}}$ & 4 & 25 & 6.5 & $\begin{array}{l}58.5^{\mathrm{b}}(\mathrm{SuBSW}) \\
98.6^{\mathrm{b}}(\mathrm{CFWW})\end{array}$ & $\begin{array}{l}81.8^{\mathrm{b}}(\mathrm{SuBSW}) 42.2^{\mathrm{b}} \\
\text { (CFWW) }\end{array}$ & $\begin{array}{l}2.07^{\mathrm{b}, \mathrm{d}} \text { (SuBSW) } 0.93^{\mathrm{b}, \mathrm{d}} \\
\text { (CFWW) }\end{array}$ & E2, this study \\
\hline $\mathrm{CFWW}^{\mathrm{c}}+$ nutrients $\left(4 \mathrm{~g}^{-\mathrm{CH} \mathrm{L}^{-1}}\right)$ & NF & CMTR & $24^{\mathrm{a}}$ & 4 & 25 & 6.5 & $98.4^{\mathrm{b}}$ & $52.97^{\mathrm{b}}$ & $0.73^{\mathrm{b}, \mathrm{d}}$ & E3, this study \\
\hline StBSW $\left(15\right.$ g-starch L $\left.{ }^{-1}\right)$ & TAS & UASB & $8-127$ & $48-3$ & 55 & 5.0 & $93-68$ & $62.5-166.7$ & $1.68-0.20^{\mathrm{e}}$ & [19] \\
\hline $\begin{array}{l}\text { CFWW + nutrients } \\
\left(4 \mathrm{~g}^{-C O D ~ L^{-1}}\right)\end{array}$ & HT-SFP & AFBR & $28-161$ & $8-1$ & 28 & 5.0 & $20-65$ & $200-2040$ & $0.31-1.91^{\mathrm{f}}$ & [20] \\
\hline CSPW $\left(2.8-4.7 \mathrm{~g}-\mathrm{CH} \mathrm{L}^{-1}\right)$ & HT-AS & APBR & $15-35^{\mathrm{a}}$ & $4-3$ & 36 & 6.0 & $84-93$ & $45.8^{\mathrm{g}}$ & $0.84^{\mathrm{h}}$ & [21] \\
\hline $\operatorname{CSBP}\left(60 \mathrm{~g}-\mathrm{COD} \mathrm{L}^{-1} ; 29.2 \mathrm{~g}-\mathrm{CH} \mathrm{L}^{-1}\right)$ & MAS & CSTR & - & $72-16$ & 60 & $5.5-5.7$ & - & $48.7-150$ & $83.0-56.7^{\mathrm{i}}$ & [24] \\
\hline $\begin{array}{l}\text { Glucose }+ \text { CSPW }^{j}(50 \% / 50 \%) \\
\quad(5 \mathrm{~g} \text {-COD L L })\end{array}$ & HT-AS & AFBR & $12-60$ & $10-2$ & 30 & $4.0-4.5$ & 97 & $42.9-87.7$ & $1.0-0.3^{\mathrm{k}}$ & [25] \\
\hline
\end{tabular}

Abbreviatures: Wastewater - CFWW = cassava flour wastewater, SuBSW $=$ sucrose-based synthetic wastewater, StBSW $=$ starch-based synthetic wastewater, CSPW $=$ cassava starch processing wastewater, CSBP = cassava stillage from bioethanol production; Inoculum - NF = natural fermentation, TAS = thermophilic acidogenic sludge, HT-SFP heat-treated sludge from facultative pond, HT$\mathrm{AS}=$ heat treated anaerobic sludge, MAS = mesophilic anaerobic sludge; Reactor $-\mathrm{CMTR}=$ continuous multiple tube reactor, UASB $=$ upflow anaerobic sludge blanket reactor, AFBR $=$ anaerobic fludized-bed reactor, APBR = anaerobic packed-bed reactor, CSTR = continuously stirred tank reactor; Operating conditions - OLR = organic loading rate, HRT = hydraulic retention time; Reactor performance - VHPR = volumetric hydrogen production rate, $\mathrm{HY}=$ hydrogen yield.

a $\mathrm{g} \mathrm{CH} \mathrm{L}^{-1} \mathrm{~d}^{-1}$

b Maximum values

c $\mathrm{CFWW}$ submitted to heat treatment $\left(121^{\circ} \mathrm{C}, 15 \mathrm{~min}\right)$

d $\mathrm{mol} \mathrm{H}_{2} \mathrm{~mol}^{-1} \mathrm{CH}$

e $\mathrm{mol} \mathrm{H}_{2} \mathrm{~mol}^{-1}$ starch

${ }^{f} \mathrm{~mol} \mathrm{H}_{2} \mathrm{~mol}^{-1}$ glucose

gaximum value (OLR $\left.=35 \mathrm{~g} \mathrm{CH} \mathrm{L}^{-1} \mathrm{~d}^{-1}\right)$

${ }^{\mathrm{h}} \mathrm{L} \mathrm{H}_{2} \mathrm{~g}^{-1} \mathrm{CH}$ - maximum value (OLR $\left.=35 \mathrm{~g} \mathrm{CH} \mathrm{L}^{-1} \mathrm{~d}^{-1}\right)$

i $\mathrm{mL} \mathrm{H}_{2} \mathrm{~g}^{-1} \mathrm{VS}$

j CSPW submitted to hydrolysis with sulfuric acid followed by heat treatment $\left(120^{\circ} \mathrm{C}, 30 \mathrm{~min}\right)$

${ }^{k} \mathrm{mmol} \mathrm{H} \mathrm{g}^{-1} \mathrm{COD}$. Range of values reported for the substrate conversion, VHPR and HY correspond to the limit values obtained for the operating conditions (i.e., OLR and HRT). 


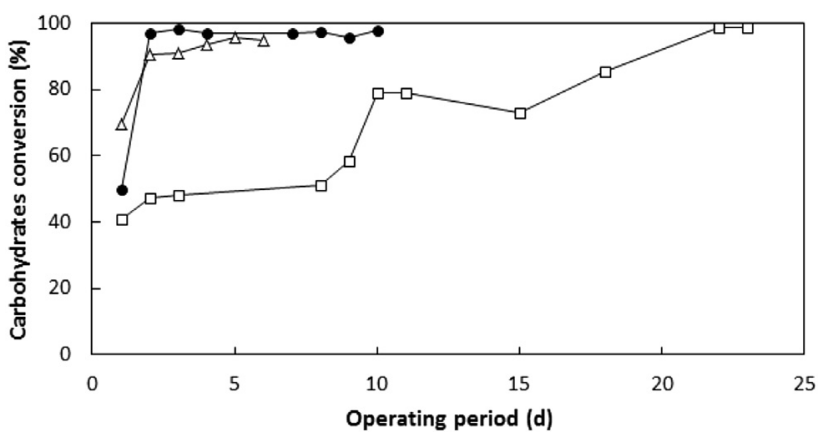

Fig. 2 - Carbohydrate conversion efficiencies in the CMTR. Legend: E1 (- $\Delta-)$, E2 (- $\square-)$ and E3 (-०-).

proportion of $\mathrm{BuH}$ observed in the raw CFWW (Fig. 4) compared to LaH.

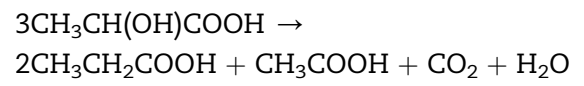

The presence of LAB, and consequently $\mathrm{LaH}$, is a common characteristic of fermentative systems, so that the literature often addresses performance losses regarding $\mathrm{BioH}_{2}$ production in such conditions, as a result from substrate competition and inhibition by $\mathrm{LaH}$ and/or bacteriocins [30]. In contrast, some studies report enhanced $\mathrm{BioH}_{2}$ production levels in fermentative systems when $\mathrm{LaH}$ is present in the organic stream applied to the reactor. Kim et al. [47] observed an increasing $\mathrm{BioH}_{2}$ production by adding up to $8 \mathrm{~g} \mathrm{~L}^{-1}$ of $\mathrm{LaH}$ to a glucose-based fermentative substrate $\left(20 \mathrm{~g} \mathrm{~L}^{-1}\right)$. Matsumoto and Nishimura [48] reported the production of hydrogen and $\mathrm{BuH}$ from the fermentation of $\mathrm{LaH}$, proposing a metabolic pathway from their experimental results (Reaction 2). However, based on the results obtained in this study, i.e., the negligible $\mathrm{BioH}_{2}$ production from CFWW, in association with the high levels of $\mathrm{PrH}$ and $\mathrm{BuH}$, different metabolic pathways rather than fermentative hydrogen production from lactic acid were most likely established in the CMTR.

$$
\begin{aligned}
& \mathrm{CH}_{3} \mathrm{COOH}+2 \mathrm{CH}_{3} \mathrm{CH}(\mathrm{OH}) \mathrm{COOH} \rightarrow \mathrm{H}_{2}+ \\
& 3 / 2 \mathrm{CH}_{3}\left(\mathrm{CH}_{2}\right)_{2} \mathrm{COOH}+2 \mathrm{CO}_{2}+\mathrm{H}_{2} \mathrm{O}
\end{aligned}
$$

$\mathrm{BuH}$ (approximately 50\%) and $\mathrm{PrH}$ (approximately 30\%) were also the main VFAs in the effluent of the reactor when the CMTR was fed with CFWW (E2 and E3, Fig. 4). The application of sucrose-based wastewater to the CMTR in E2 led to a similar VFA distribution as those in packed-bed acidogenic systems processing lab-made wastewater $[8,9,11]$ with acetic acid $(\mathrm{AcH})$ and $\mathrm{BuH}(50-60 \%)$ as the main metabolites (data not shown). A comparison of the influent and effluent concentrations when CFWW was used as the substrate shows a decrease in the concentration of $\operatorname{PrH}$ (Fig. 4), whereas the levels of $\mathrm{BuH}$ increased. Some $\mathrm{PrH}$ degradation pathways include the formation of $\mathrm{BuH}$ and $\mathrm{AcH}[45,49]$. de Bok et al. [49]
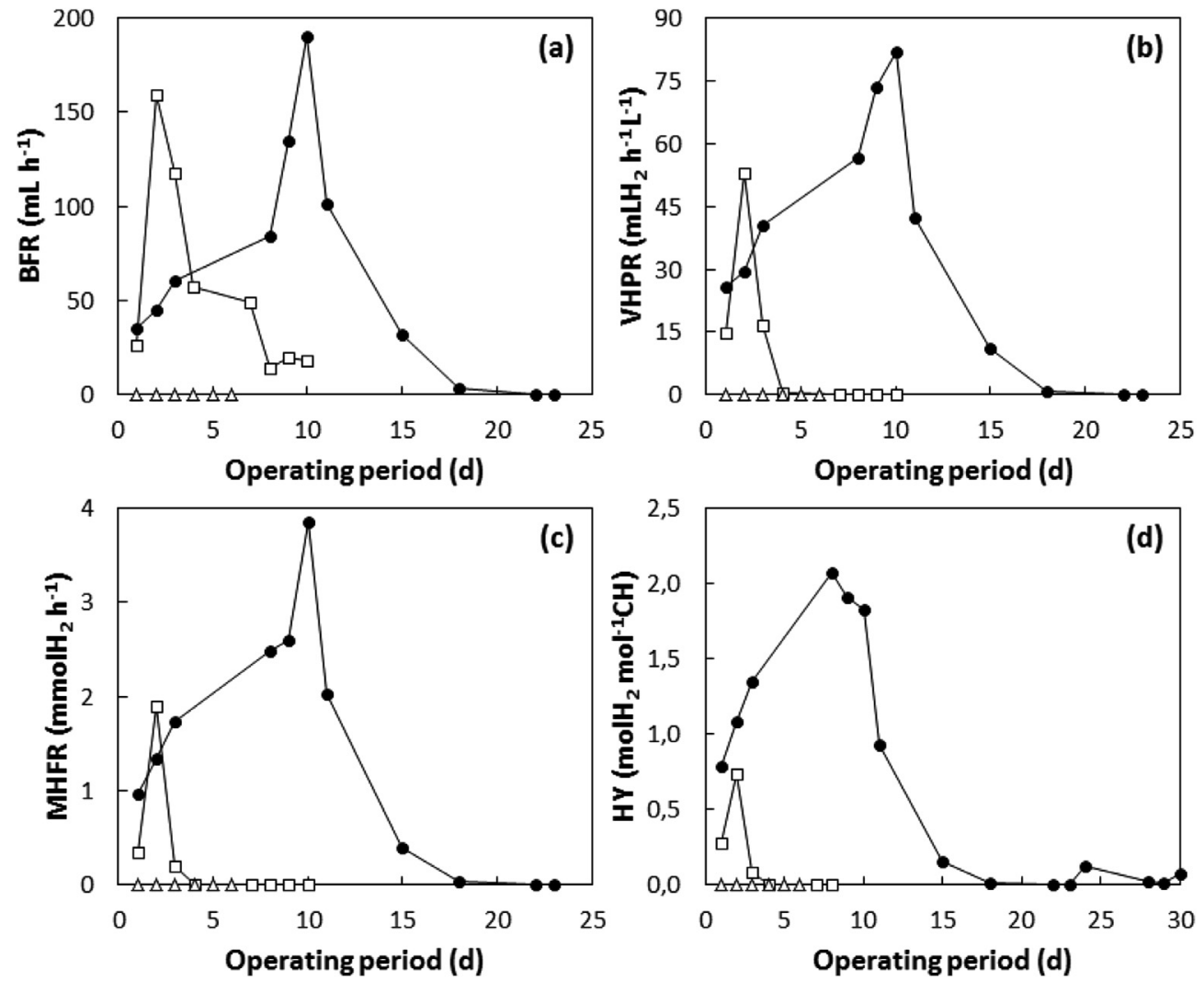

Fig. 3 - Temporal profiles of the (a) biogas flow rate (BFR), (b) volumetric hydrogen production rate (VHPR), (c) molar

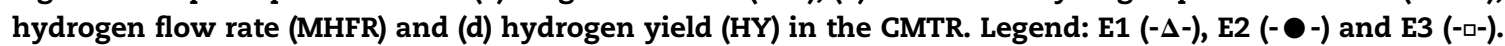




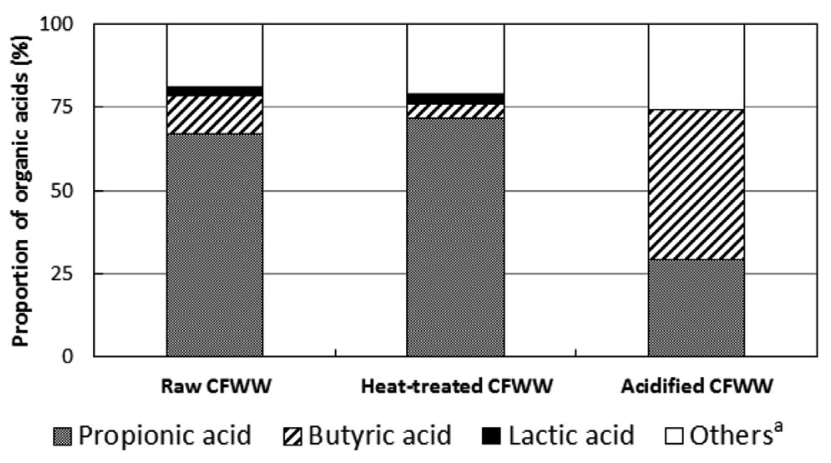

Fig. 4 - Proportions of organic acids in the raw, heattreated and acidified ${ }^{\mathrm{b}}$ CFWW. Notes: ${ }^{\mathrm{a}}$ Includes citric, malic, succinic, formic, acetic, isobutyric, isovaleric, valeric and caproic acids. b Average values calculated from the proportions of VFAs in E2 and E3.

reported propionate oxidation by Smithella propionica through the formation of a six-carbon (6C) compound from two molecules of propionate, which is then cleaved to form acetate (2C) and butyrate (4C). Madigan et al. [45] also reported the degradation of propionate by microorganisms from the Syntrophobacter genus. The higher concentrations of $\mathrm{BuH}$ in the acidified CFWW may also be associated with the conversion of lactic acid by butyrate-producing bacteria [33,47,48], which could also explain the absence of $\mathrm{LaH}$ in the effluent of the CMTR.

The inhibition of hydrogen production by organic acids may result from either their input through the influent wastewater or their concentration as soluble metabolic products from fermentation [50-53]. Initially, such acids permeate the cell membrane of bacteria as undissociated compounds. The subsequent dissociation of the acids in the cytoplasm enhances the release of $\mathrm{H}^{+}$ions, and the microorganisms are then forced to direct more energy to maintain the physiological balance, which limits cell growth. The accumulation of dissociated acids in the cell further increases the ionic strength, which may result in cell lysis [50-52].

Wang et al. [52] evaluated the inhibitory effects of ethanol, $\mathrm{AcH}, \mathrm{PrH}$ and $\mathrm{BuH}$ on fermentative hydrogen production by adding different concentrations $\left(0-300 \mathrm{mmol} \mathrm{L}^{-1}\right)$ of these compounds in batch tests using glucose $\left(1 \mathrm{~g} \mathrm{~L}^{-1}\right)$ as the carbon source. Regardless of the compound, hydrogen production occurred at concentrations of up to $200 \mathrm{mmol} \mathrm{L}^{-1}$ (i.e., $14.8 \mathrm{~g} \mathrm{~L}^{-1}$ for PrH and $17.6 \mathrm{~g} \mathrm{~L}^{-1}$ for $\left.\mathrm{BuH}\right)$. Zheng and $\mathrm{Yu}$ [51] tested the effects of $\mathrm{BuH}$ on hydrogen fermentation from glucose and found that moderate inhibitory patterns were observed only for BuH concentrations from 8.36 to $12.54 \mathrm{~g} \mathrm{~L}^{-1}$ van Ginkel and Logan [50] also studied the influence of high levels of $\mathrm{AcH}$ and $\mathrm{BuH}$ on hydrogen production from glucose. The concentration of acids was increased by adding these compounds as external sources or by increasing the concentration of glucose to enhance the production of acids by the bacteria. The results indicated that hydrogen production was more inhibited by self-produced acids in systems operated with higher concentrations of glucose (19 $\mathrm{mM}$ was the critical concentration of total undissociated acids) than by similar levels of externally added acids with lower concentrations of glucose $(60 \mathrm{mM}$ was the critical concentration of total undissociated acids).

The average concentrations of organic acids in the heattreated and acidified CFWW (E2 and E3) ranged from 1.3 to 4.0 and from 1.0 to $3.0 \mathrm{~g} \mathrm{~L}^{-1}$, respectively. Therefore, a slight inhibition of hydrogen production by the organic acids may have occurred in this study based on the inhibitory VFA concentrations reported in the aforementioned investigations. However, the VFA levels observed in this study most likely did not reflect the sharp decrease in hydrogen production from the heat-treated CFWW (E2 and E3). Thus, the inhibitory process of hydrogen production was controlled by other metabolic compounds, such as bacteriocins.

\section{Identification of bacteriocins in the CFWW}

The presence of bacteriocins in the CFWW used in this study was confirmed by analyzing the samples by LC-MS/MS as previously reported [41]. The bacteriocins Nisin A and Nisin Z as well as their degradation products in both the raw and heat-treated CFWW samples were detected. Their presence suggests that the poor results observed in all three assays could be attributed to these compounds. Fig. 5 shows the chromatograms that were obtained for the raw CFWW. Bacteriocins are natural antimicrobial peptides, ribossomally synthesized, secreted by many types of bacteria, in order to provide such microorganisms with a competitive advantage in their environment [54]. LAB are a diverse group of microorganisms normally related to bacteriocin production [54,55], which is a process commonly associated with cell growth $[56,57]$. Therefore, the factors affecting biomass production, such as culture $\mathrm{pH}$, cultivation method and the type and concentration of the carbon, nitrogen and phosphorus sources, should affect bacteriocin production, [57,58].

Nisin is an antimicrobial peptide that is produced by certain strains of Lactococcus lactis and has practical applications as a food preservative [59]. The presence of Nisin in the CFWW indicates that the natural fermentation of the CFWW was promoted by LAB, which converted some of the carbohydrates into lactate. The lactate was further converted into propionate by the PrH bacteria, as previously discussed. Nisin $A$ and Nisin $Z$ are highly effective against microbial agents that cause food poisoning and spoilage [44]. The main mechanism of action of Nisin is based on its association with lipid II, which is an essential intermediate in cell wall biosynthesis, promoting the formation of pores in the cell membrane and then inducing the efflux of small molecules from the cell $[56,60]$.

Noike et al. [30] also associated the excretion of bacteriocins by LAB with inhibitory effects on hydrogen production in the anaerobic fermentation of bean curd manufacturing waste. They observed that the hydrogen fermentation process was replaced by the lactic acid fermentative pathway; however, the bacteriocin activity could be completely destroyed by heating the substrate to $50{ }^{\circ} \mathrm{C}$ for $30 \mathrm{~min}$. In another study, Obadina et al. [43] observed that the fermentation process of cassava "fufu" by Lactobacillus plantarum reduced the level of pathogens as a direct result of the production of antimicrobial 

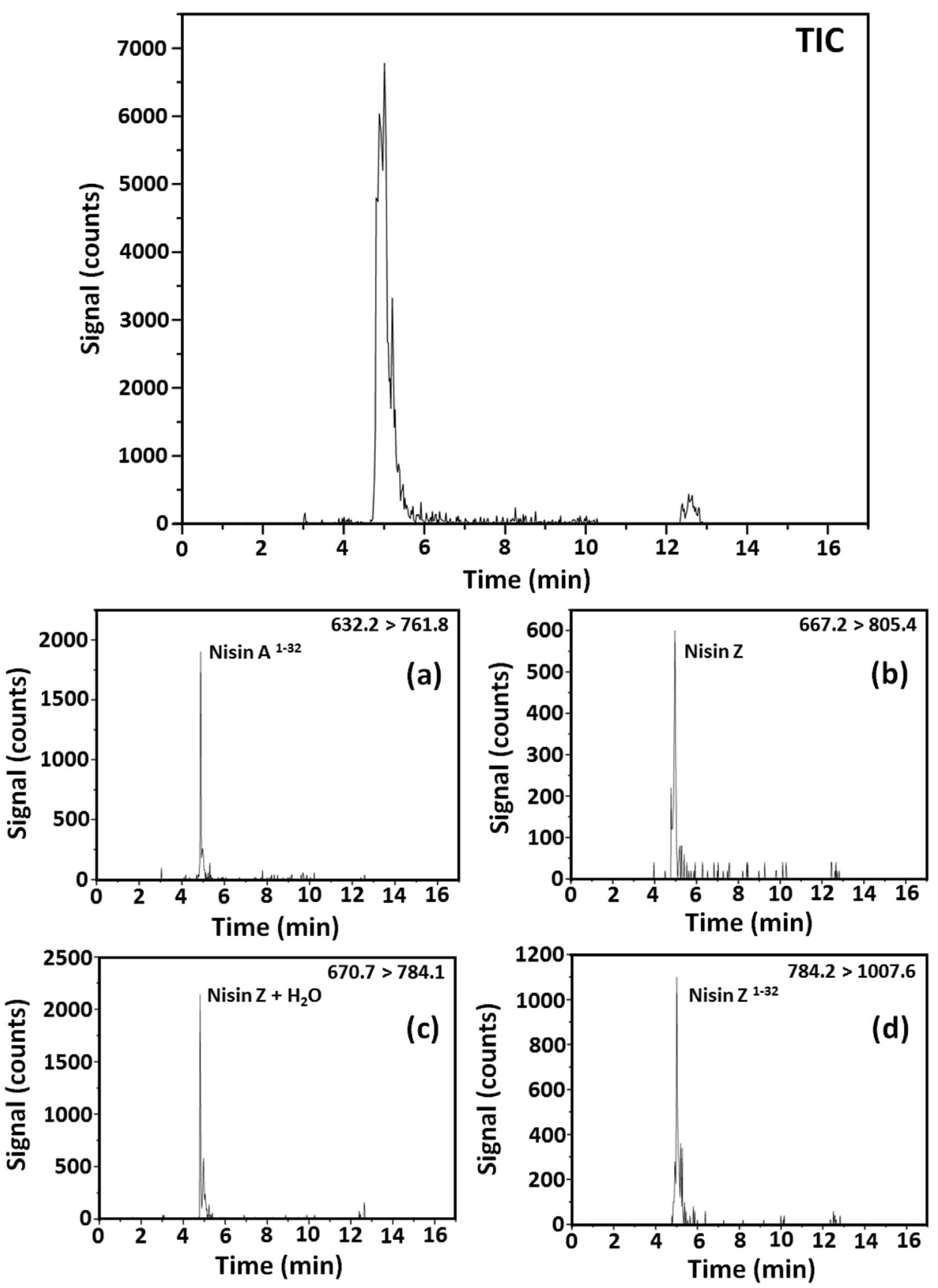

Fig. 5 - Total ion chromatogram of the CFWW obtained by LC-MS/MS and extracted ion chromatograms of (a) Nisin A metabolite, (b) Nisin Z, (c) Nisin Z metabolite 1 and (d) Nisin Z metabolite 2.

substances by LAB. Rosa et al. [25] performed a phylogenetic identification using the 16S rRNA gene for the Bacteria domain in an AFBR processing a mixture of cassava wastewater and glucose as substrates. They observed that $92.4 \%$ of the sequences corresponded to the family Lactobacillaceae. The authors considered this dominance of Lactobacillus as a possible reason for the absence of Clostridium-like bacteria, based on the inhibitory effects of the bacteriocins produced by LAB. Mante et al. [28] studied the fermentation of cassava dough into agbelima, which is a smooth sour cassava dough, and observed that 12 isolates of Lactobacillus plantarum had inhibitory effects on some microorganisms. However, none of the isolates tested positive for bacteriocin production, and the authors attributed the inhibitory effects to acid production, differently from this study.

Finally, the identification of bacteriocins in the heattreated CFWW samples suggests the heat stability of such compounds under the conditions employed in this study $\left(121{ }^{\circ} \mathrm{C}, 15 \mathrm{~min}, \mathrm{pH}=5.0\right)$. In fact, several studies have demonstrated that the heat treatment of wastewaters may not completely deactivate bacteriocins. Noonpakdee et al. [31] evaluated the effects of heat and $\mathrm{pH}$ on the activity of 
bacteriocins and found that their inhibitory effects remained even after exposure to elevated temperatures at pH $3.0\left(121{ }^{\circ} \mathrm{C}, 15 \mathrm{~min}\right)$. At pH 5.0 and the same heating conditions, the inhibitory activity decreased by $97 \%$; at $\mathrm{pH}$ 7.0, the inhibitory activity was prevented. Because in this study CFWW was subjected to heat treatment at $\mathrm{pH}$ values of approximately 5.0, the bacteriocin activity was likely not effectively suppressed. In the study of Zacharof and Lovitt [44], although the application of high temperatures $(40,60$, 80 and $100^{\circ} \mathrm{C}$ for periods of $15,30,45$ and $60 \mathrm{~min}$ ) negatively affected the activity of bacteriocins, they remained relatively stable under certain conditions. At $40{ }^{\circ} \mathrm{C}$, the activity of Nisin against the target strain remained relatively unaffected, whereas at $60{ }^{\circ} \mathrm{C}$ the activity was affected only by treatments that were longer than $60 \mathrm{~min}$. At $80^{\circ} \mathrm{C}$, negative effects on the Nisin activity were observed at $45 \mathrm{~min}$, while at $100{ }^{\circ} \mathrm{C}$, the effects were observed regardless of the duration of the treatment. Teo and Tan [34] also observed that different heat treatments $\left(70,80,90,100\right.$ and $121{ }^{\circ} \mathrm{C}$ for $15 \mathrm{~min}$ ) caused negligible reductions in the anticlostridial activities of the filtrates from Bacillus subtilis PB6 compared with the unheated filtrate.

\section{Conclusions}

The results of this study indicated that the type of cassava wastewater may significantly affect hydrogen production in fermentative systems, depending on the type of microorganisms and soluble compounds present in the wastewater. Although the carbohydrate conversion efficiencies exceeded $90 \%$, little to no hydrogen production was observed regardless of the experimental conditions. The poor hydrogenogenic performances could be attributed to two major types of metabolites - organic acids, especially propionic and butyric acids, and bacteriocins - due to the presence of lactic acid bacteria. Despite the considerable concentrations of organic acids in CFWW, these levels most likely did not reflect the sharp decrease in hydrogen production from the heat-treated CFWW. Thus, the inhibitory process of hydrogen production was primarily regulated by the bacteriocins, specifically Nisin A and Nisin Z. Additional assays should be carried out to evaluate the potential to produce hydrogen from the CFWW in the CMTR, considering both the positive results that have been described in the literature for cassava wastewaters and the feasibility of applying the CMTR to acidogenic systems. Additionally, for such purposes more effective methods to inactivate bacteriocins should be tested.

\section{Acknowledgments}

The authors gratefully acknowledge the National Council for Scientific and Technological Development (CNPq, grant number 150403/2013-5) and the São Paulo Research Foundation (FAPESP, grant number 2009/15984-0) for their financial support.

\section{R E F E R E N C E S}

[1] Show KY, Lee DJ, Tay JH, Lin CY, Chang JS. Biohydrogen production: current perspectives and the way forward. Int $J$ Hydrogen Energy 2012;37:15616-31.

[2] Arimi MM, Knodel J, Kiprop A, Namango SS, Zhang Y, Geißen SU. Strategies for improvement of biohydrogen production from organic-rich wastewater: a review. Biomass Bioenergy 2015;75:101-18.

[3] Bakonyi P, Nemestóthy N, Simon V, Bélafi-Bakó K. Review on the start-up experiences of continuous fermentative hydrogen producing bioreactors. Renew Sust Energy Rev 2014;40:806-13.

[4] Hafez H, Baghchehsaraee B, Nakhla G, Karamanev D, Margaritis A, Naggar H. Comparative assessment of decoupling of biomass and hydraulic retention times in hydrogen production bioreactors. Int J Hydrogen Energy 2009;34:7603-11.

[5] Fernandes BS, Saavedra NK, Maintinguer SI, Sette LD, Oliveira VM, Varesche MBA, et al. The effect of biomass immobilization support material and bed porosity on hydrogen production in na upflow anaerobic packed-bed bioreactor. Appl Biochem Biotech 2013;170:1348-66.

[6] Bakonyi P, Nemestóthy N, Simon V, Bélafi-Bakó K. Fermentative hydrogen production in anaerobic membrane bioreactors: a review. Bioresour Technol 2014;156:357-63.

[7] Fontes Lima DM, Zaiat M. The influence of the degree of back-mixing on hydrogen production in an anaerobic fixedbed reactor. Int J Hydrogen Energy 2012;37:9630-5.

[8] Fontes Lima DM, Moreira WK, Zaiat M. Comparison of the use of sucrose and glucose as substrate for hydrogen production in an upflow anaerobic fixed-bed reactor. Int J Hydrogen Energy 2013;38:15074-83.

[9] Penteado ED, Lazaro CZ, Sakamoto IK, Zaiat M. Influence of seed sludge and pretreatment method on hydrogen production in packed-bed anaerobic reactors. Int J Hydrogen Energy 2013;38:6137-45.

[10] Hafez H, Nakhla G, Naggar HE, Elbeshbishy E, Baghchehsaraee B. Effect of organic loading on a novel hydrogen bioreactor. Int J Hydrogen Energy 2010;35:81-92.

[11] Anzola-Rojas MP, Fonseca SG, Silva CC, Oliveira VM, Zaiat M. The use of the carbon/nitrogen ratio and specific organic loading rate as tools for improving biohydrogen production in fixed-bed reactors. Biotechnol Rep 2015;5:46-54.

[12] Anzola-Rojas MP, Zaiat M. A novel anaerobic down-flow structured-bed reactor for long-term stable $\mathrm{H}_{2}$ energy production from wastewater. J Chem Technol Biotechnol 2015. http://dx.doi.org/10.1002/jctb.4754.

[13] Saddy NMC. Homoacetogenesis during hydrogen production by mixed cultures dark fermentation. Int J Hydrogen Energy 2013;38:13172-91.

[14] Lee DY, Li YY, Noike T. Influence of solids retention time on continuous $\mathrm{H}_{2}$ production using membrane bioreactor. Int $\mathrm{J}$ Hydrogen Energy 2010;35:52-60.

[15] Gomes SD, Fuess LT, Penteado ED, Lucas SDM, Gotardo JT, Zaiat M. The application of an innovative continuous multiple tube reactor as a strategy to control the specific organic loading rate for biohydrogen production by dark fermentation. Bioresour Technol 2015;197:201-7.

[16] Froment GF. Fixed bed reactor design. In: Whitaker S, Cassano AE, editors. Concepts and design of chemical reactors. New York: Gordon and Breach Science Publishers; 1986. p. 179-212.

[17] Lin CY, Lay CH, Sen B, Chu CY, Kumar G, Chen CC, et al. Fermentative hydrogen production from wastewaters: a review and prognosis. Int J Hydrogen Energy 2012;37:15632-42. 
[18] Damasceno S, Cereda MP, Pastore GM, Oliveira JG. Production of volatile compounds by Geotrichum fragrans using cassava wastewater as substrate. Process Biochem 2003;39:411-4.

[19] Akutsu Y, Lee DY, Chi YZ, Li YY, Harada H, Yu HQ. Thermophilic fermentative hydrogen production from starch-wastewater with bio-granules. Int J Hydrogen Energy 2009;34:5061-71.

[20] Amorim NCS, Alves I, Martins JS, Amorim ELC. Biohydrogen production from cassava wastewater in an anaerobic fluidized bed reactor. Braz J Chem Eng 2014;31:603-12.

[21] Andreani AL, Torres DGB, Schultz L, Carvalho KQ, Gomes SD. Hydrogen production from cassava processing wastewater in an anaerobic fixed bed reactor with bamboo as the support material. Eng Agríc 2015;35:578-87.

[22] Lucas SDM, Peixoto G, Mockaitis G, Zaiat M, Gomes SD Energy recovery from agro-industrial wastewaters through biohydrogen production: kinetic evaluation and technological feasibility. Renew Energy 2015;75:496-504.

[23] Sreethawong T, Suchavadee C, Pramoch R, Sumaeth C. Hydrogen production from cassava wastewater using an anaerobic sequencing batch reactor: effects of operational parameters, COD: N ratio, and organic acid composition. Int J Hydrogen Energy 2010;35:4092-102.

[24] Luo G, Xie L, Zou Z, Wang W, Zhou Q. Exploring optimal conditions for thermophilic fermentative hydrogen production from cassava stillage. Int J Hydrogen Energy 2010;35:6161-9.

[25] Rosa PRF, Santos SC, Sakamoto IK, Varesche MBA, Silva EL. The effects of seed sludge and hydraulic retention time on the production of hydrogen from a cassava processing wastewater and glucose mixture in an anaerobic fluidized bed reactor. Int J Hydrogen Energy 2014;39:13118-27.

[26] Wang W, Xie L, Luo G, Zhou Q. Enhanced fermentative hydrogen production from cassava stillage by co-digestion: the effects of different co-substrates. Int J Hydrogen Energy 2013;38:6980-8.

[27] Show KY, Lee DJ, Chang JS. Bioreactor and process design for biohydrogen production. Bioresour Technol 2011;102:8524-33.

[28] Mante ES, Sakyi-Dawson E, Amoa-Awua WK. Antimicrobial interactions of microbial species involved in the fermentation of cassava dough into agbelima with particular reference to the inhibitory effect of lactic acid bacteria on enteric pathogens. Int J Food Microbiol 2003;89:41-50.

[29] Castro-Villalobos MC, García-Morales JL, Fernández FJ. Byproducts inhibition effects on bio-hydrogen production. Int Hydrogen Energy 2012;37:7077-83.

[30] Noike T, Takabatake H, Mizuno O, Ohba M. Inhibition of hydrogen fermentation of organic wastes by lactic acid bacteria. Int J Hydrogen Energy 2002;27:1367-71.

[31] Noonpakdee W, Santivarangkna C, Jumriangrit P, Sonomoto K, Panyim S. Isolation of nisin-producing Lactococcus lactis WNC 20 strain from nham, a traditional Tha fermented sausage. Int J Food Microbiol 2003;81:137-45.

[32] Bruno MEC, Montville TJ. Common mechanistic action of bacteriocins from lactic acid bacteria. Appl Environ Microb 1993;59(9):3003-10.

[33] Gomes BC, Rosa PRF, Etchebehere C, Silva EL, Varesche MBA. Role of homo- and heterofermentative lactic acid bacteria on hydrogen-producing reactors operated with cheese whey wastewater. Int J Hydrogen Energy 2015;40:8650-60.

[34] Teo AYL, Tan HM. Inhibition of Clostridium perfringens by a novel strain of Bacillus subtilis isolated from the gastrointestinal tracts of healthy chickens. Appl Environ Microb 2005;71:4185-90.

[35] Leaño EP, Babel S. Effects of pretreatment methods on cassava wastewater for biohydrogen production optimization. Renew Energy 2012;39:339-46.
[36] Del Nery V. Utilização de lodo anaeróbio imobilizado em gel no estudo de partida de reatores de fluxo ascendente com manta de lodo (Use of anaerobic sludge immobilized in gel to study the start-up of upflow anaerobic sludge blanket reactors), M.Sc. dissertation. University of São Paulo; 1987 [in Portuguese].

[37] Leite J, Fernandes BS, Pozzi E, Barboza M, Zaiat M. Application of an anaerobic packed-bed bioreactor for the production of hydrogen and organic acids. Int J Hydrogen Energy 2008;33:579-86.

[38] APHA, AWWA, WEF. Standard methods for the examination of water and wastewater. 21th ed. Washington DC: APHA; 2005.

[39] Dubois SM, Gilles KA, Hamilton JK, Rebers PA, Smith F. Colorimetric methods for determination of sugar and related substance. Anal Chem 1956;228:13-21.

[40] Perna V, Castelló E, Wenzel J, Zampol C, Fontes Lima DM, Borzacconi L, et al. Hydrogen production in an upflow anaerobic packed bed reactor used to treat cheese whey. Int J Hydrogen Energy 2013;38:54-62.

[41] Schneider N, Werkmeister K, Pischetsrieder M. Analysis of nisin A, nisin Z and their degradation products by LCMS/MS. Food Chem 2011;127:847-54.

[42] Cappelletti BM, Reginatto V, Amante ER, Antônio RV. Fermentative production of hydrogen from cassava processing wastewater by Clostridium acetobutylicum. Renew Energy 2011;36:3367-72.

[43] Obadina AO, Oyewole OB, Sanni LO, Tomlins KI. Biopreservative activities of Lactobacillus plantarum strains in fermenting Cassava 'fufu'. Afr J Biotechnol 2006;5:620-3.

[44] Zacharof MP, Lovitt RW. Investigation of shelf life of potency and activity of the Lactobacilli produced bacteriocins through their exposure to various physicochemical stress factors. Probiotics Antimicrob Proteins 2012;4:187-97.

[45] Madigan MT, Martinko JM, Bender KS, Buckley DH, Stahl DA. Brock biology of microorganisms. 14th ed. Boston: Pearson College Division; 2014.

[46] Seeliger S, Janssen PH, Schink B. Energetics and kinetics of lactate fermentation to acetate and propionate via methylmalonyl-CoA or acrylyl-CoA. FEMS Microbiol Lett 2002;211:65-70.

[47] Kim TH, Lee Y, Chang KH, Hwang SJ. Effects of initial lactic acid concentration, HRTs, and OLRs on bio-hydrogen production from lactate-type fermentation. Bioresour Technol 2012;103:136-41.

[48] Matsumoto M, Nishimura Y. Hydrogen production by fermentation using acetic acid and lactic acid. J Biosci Bioeng 2007;103:236-41.

[49] de Bok FAM, Stams AJM, Dijkema C, Boone DR. Pathway of propionate oxidation by syntrophic culture of Smithella propionica and Methanospirillum hungatei. Appl Environ Microb 2001;67:1800-4.

[50] van Ginkel S, Logan BE. Inhibition of biohydrogen production by undissociated acetic and butyric acids. Environ Sci Technol 2005;39:9351-6.

[51] Zheng XJ, Yu HQ. Inhibitory effects of butyrate on biological hydrogen production with mixed anaerobic cultures. J Environ Manage 2005;74:65-70.

[52] Wang B, Wan W, Wang J. Inhibitory effect of ethanol, acetic acid, propionic acid and butyric acid on fermentative hydrogen production. Int J Hydrogen Energy 2008;33:7013-9.

[53] Sivagurunathan P, Sen B, Lin CY. Overcoming propionic acid inhibition of hydrogen fermentation by temperature shift strategy. Int J Hydrogen Energy 2014;39:19232-41.

[54] Elayaraja S, Annamalai N, Mayavu P, Balasubramanian T. Production, purification and characterization of bacteriocin from Lactobacillus murinus AU06 and its broad antibacterial spectrum. Asian Pac J Trop Biomed 2014;4(Suppl. 1):S30511. 
[55] Jack RW, Tagg JR, Ray B. Bacteriocins of gram-positive bacteria. Microbiol Rev 1995;59:171-200.

[56] Bierbaum G, Sahl HG. Lantibiotics: mode of action, biosynthesis and bioengineering. Curr Pharm Biotechnol 2009;10:2-18.

[57] Pérez RA, González EA, Agrasar AT, Guerra NP. A review on some important factors affecting bacteriocin production by Lactococci, Lactobacilli and Pediococci. Curr Biochem Eng 2014;1:9-24.
[58] Yang R, Ray B. Factors influencing production of bacteriocins by lactic acid bacteria. Food Microbiol 1994;11:281-91.

[59] Rodríguez JM, Cintas LM, Casaus P, Horn N, Dodd HM, Hernández PE, et al. Isolation of nisin-producing Lactococcus lactis strains from dry fermented sausages. J Appl Bacteriol 1995;78:109-15.

[60] Nagao J. Properties and applications of lantibiotics, a class of bacteriocins produced by gram-positive bacteria. J Oral Biosci 2009;51:158-64. 